\title{
Sistem Pasca Westphalia, Interaksi Transnasional dan Paradiplomacy
}

\section{Takdir Ali Mukti}

Jurusan IImu Hubungan Internasional, Fakultas IImu Sosial dan IImu Politik, Universitas Muhammadiyah Yogyakarta

Ringroad Barat Tamantirto, Kasihan, Bantul 55183

Email: takdirjogja1@gmail.com

\begin{abstract}
Understanding world history will lead to understand world life today. World politics or international relations experiences many periodical momentums along the centuries, from barbarian to institutionalized system in Westphalia Treaty, with a lot of historical facts such as colonialism, world wars and cold war. The further period is from Westphalian system to post Westphalian system, where international societies have changed dramatically. This article will explore the new world system nowadays, and the responds of local actors in transnational relations.

Keyword: Westphalia, Worldpolitics, transnational, paradiplomacy
\end{abstract}

\begin{abstract}
Abstrak
Memahami sejarah dunia akan menuntun pada pemahaman kehidupan dunia sekarang, Politik dunia atau hubungan internasional mengalami banyak momentum sepanjang abad, dari sistem barbar hingga sistem yang dilembagakan di perjanjian Westphalia dengan fakta-fakta sejarah seperti kolonialisme, perang dunia dan perang dingin. Periode selanjutnya adalah dari sistem Westphalia ke sistem Westphalian dimana masyarakat internasional berubah dengan dramatis. Tulisan ini akan membahas sistem baru dunia sekarang dan respon aktor lokal dalam hubungan transnasional.
\end{abstract}

Kata Kunci: Westphalia, politik dunia, transnasional, paradiplomasi

\section{PENDAHULUAN}

Ketika Peer Schouten mengajukan pertanyakan kepada Joseph Nye Jr.: 'Dalam dunia internasional seperti apa, kita hidup saat ini?', Nye menyatakan bahwa dewasa ini kita hidup di jaman hibrid. Sebagian dari dunia kita yang positif-normatif, serta berbasis pada 'kedaulatan negara' adalah 'doktrin' Westphalian, sedangkan di bagian lain adalah model post-Westphalia, yang di dalamnya aktor-aktor transnasional dan norma-norma hukum humaniter internasional menerabas melintasi batas-batas kedaulatan negara. Kedua bagian ini tampaknya masih akan terjadi untuk beberapa dekade ke depan, sehingga analisis positif dan normatif yang baik akan mencakup keduanya (Schoulten, 2008).
Perjanjian Westphalia atau The Peace of Westphalia atau The Westphalia Treaty, tahun 1648, di Jerman, mengakhiri Perang Eropa selama 30 tahun, berhasil memancangkan tonggak sejarah bernegara secara modern dalam konsep nation-state dan menjadi permulaan bagi terjadinya sistem hubungan internasional secara modern, yang disebut sebagai Westphalian System (Osiander, 2001). Doktrin Westphalian hasil dari perjanjian ini meliputi prinsip penghormatan atas kedaulatan suatu negara dan hak untuk menentukan nasib sendiri suatu bangsa, kemudian prinsip kesamaan di depan hukum bagi setiap negara, dan prinsip non-intervensi atas urusan internal negara lain. Sebagaimana dikatakan oleh 
Watson bahwa Perjanjian Westphalia melegitimasi persemakmuran negara-negara berdaulat, yang menandai kemenangan negara dalam mengendalikan masalah-masalah internalnya, dan menjaga kemerdekaannya secara ekternal. Perjanjian ini banyak melahirkan aturan dan prinsip politik bagi negaranegara baru (Watson, 2009). Fakta historis tentang prinsip bernegara secara modern dalam The Westphalia Treaty ini bagi para penstudi ilmu hubungan internasional, terutama kalangan teoritisi realistradisionalis, dianggap merupakan titik awal terjadinya studi ilmu hubungan internasional modern.

Gugatan terhadap pendekatan para realistradisionalis tak terbendung lagi seiring dengan semakin menyatunya sistem ekonomi dunia yang ditunjang dengan penyatuan sistem teknologi informasi dalam jaringan yang bersifat world wide. Demikian pula dengan perilaku masyarakat internasional yang semakin fleksibel, baik secara institusional maupun individual, untuk melakukan interaksi yang bersifat transnasional, dimana aktoraktor pemerintahan lokal pun secara langsung ikut berinteraksi dengan pihak asing dalam kapasitasnya selaku sub-state actors, atau apa yang lebih dikenal sebagai paradiplomacy. Pertanyaannya adalah, bagaimana gambaran riil konstruksi hubungan antarbangsa saat ini, dan bagaimana aktor-aktor lokal dalam merespon interaksi transnasional itu?

\section{PEMBAHASAN}

HUBUNGAN DAN KERJASAMA INTERNASIONAL DEWASA INI

Para teoritisi konstruktivis dan praktisi hubungan internasional dewasa ini, lebih melihat bahwa era Westphalian Doctrines telah tidak relevan lagi dalam pergaulan masyarakat dunia yang sangat interns dan terbuka seiring dengan kemajuan teknologi informasi. Andreas Osiander menyatakan bahwa Westphalian System dengan konsep kedaulatannya sebagai pilar utama, telah menjadi perdebatan secara internasional. Pertanyaan mengenai apakah pilar-pilar sistem Westphalia telah rapuh saat ini, dan sistem internasional dewasa ini sedang bergerak ke arah beyond
Westphalian (Osiander, 2001 253)

Gugatan atas relevansi juga sangat terasa di tempat asal dari doktrin Westphalia tersebut, yakni di Eropa, yang telah mengarah pada terbentuknya masyarakat Uni Eropa yang menyatu secara ekonomi, politik dan kultural. Hal ini tergambar jelas dalam pidato Sekretaris General NATO, Dr Javier Solana dalam Symposium on the Political Relevance of the 1648 Peace of Westphalia, di Mnster, German, 12 November 1998, yang mengatakan bahwa:

"It is my general contention that humanity and democracy - two principles essentially irrelevant to the original Westphalian order - can serve as guideposts in crafting a new international order, better adapted to the security realities, and challenges, of today's Europe. The Westphalian Peace, signed here in Mnster, was the first allEuropean peace after the first all-European war. It has shaped our thinking about the structure of the international system, and thus about war and peace, perhaps more than any other single event in the last 350 years. Yet the Westphalian system had its limits. For one, the principle of sovereignty it relied on also produced the basis for rivalry, not community of states; exclusion, not integration. In the end, it was a system that could not guarantee peace. Nor did it prevent war, as the history of the last three centuries has so tragically demonstrated."

(Nato, 1998)

Solana berpandangan bahwa prinsip humanitas dan demokrasi merupakan dua prinsip yang secara esensial tidak relevan terhadap order Westphalia, lebih bisa diadopsi untuk menjadi acuan dalam membangun sistem internasional yang baru, sebab sistem Westphalia mengandung sejumlah kelamahan. Sistem Westphalia dibangun di atas fondasi kedaulatan mutlak sebuah negara yang memunculkan rivalitas satu sama lain, dan tidak menciptakan sebuah komunitas negara-negara atau komunitas internasional yang damai. Kedaulatan adalah sebuah esklusi sehingga tidak berfungsi intergrasi. Pada akhirnya, sistem Westphalia tidak mampu menjamin keamanan sebagaimana yang terjadi selama tiga abad lamanya.

Mengapa Eropa menjadi sangat merasakan 
pergeseran sistem Westphalia ini, bahkan untuk yang pertama kalinya dibandingkan dengan belahan dunia yang lain? Hal ini tidak dapat dipisahkan dari perkembangan dramatis kerjasama ekonomi Eropa yang kemudian tumbuh menjadi Uni Eropa seperti sekarang ini, dimana batas-batas negara menjadi sangat kabur, dan bahkan oleh sebagian besar penduduknya dianggap sebagai 'pengganggu yang merepotkan' mobilitas mereka saja. Intergrasi Eropa memunculkan gejala yang secara prinsip berlawanan dengan semangat Westphalian, yakni sebuah proses de-bordering the world of states, sebagaimana dikatakan oleh Hüsamettin Inanc dan Hayrettin Ozler:

'Declining transaction costs and cost of organizational connections across national boundaries have increased the flow of information, capital, service, goods and people around the globe. This so-called globalization phenomenon is expected to close the gap between cultural, economic and political differences. Yet globalization does not always mean association between national political and economic societies or the emergence of a global society. The fact seems to be rather a process of 'de-bordering the world of states' in which the governments or the nation states diffuse to or 'share' their exclusive policy-making power with some international and sub-national actors. This conception signals the emergence of a novice political order beyond so-called the Westphalian system.' (Inanc dan Ozler, 2007)

Dalam pandangan Inanc dan Ozler, fenomena globalisasi yang terjadi karena peningkatan arus informasi, modal, layanan dan lalu lintas orang dan barang, diharapkan dapat menutup kesenjangan diantara perbedaan-perbedaan budaya, politik dan ekonomi antar bangsa, meskipun globalisasi tidak selalu berarti terjadinya kesatuan secara ekonomi dan politik masyarakat suatu negara. Fakta menunjukkan bahwa globalisasi lebih merupakan proses de-bordering atau proses peniadaan batas-batas negara diantara bangsa-bangsa di dunia, dimana negara-negara melakukan share atas otoritas esklusive pembuatan kebijakannya dengan aktor internasional dan juga dengan aktor-aktor sub-nasionalnya. Konsepsi tersebut memunculkan sebuah tatanan politik baru di luar apa yang biasa disebut sebagai Sistem Westphalia.

Tatanan pasca sistem Westphalia yang cenderung mengabaikan batas negara atau de-bordering ini mendobrak pengertian 'hubungan internasional' kovensional menjadi 'hubungan transnasional' yang lebih kompleks, dan dalam batas-batas tertentu lebih partisipatif, sekaligus mengandung potensi konflik. Pemaknaan istilah 'international relations' yang berarti hubungan 'antar bangsa' (inter-nation), menjadi kurang mewadahi aktor-aktor 'non-negara' (non-nation/state). Dalam kajian ini, Robert C. Keohane memberikan kontribusi terbesar dalam pengembangan teoritis transnasionalisme sejak tahun 1970-an. Dia secara kreatif tidak terjebak dengan issu dunia yang mainstream saat itu yakni Perang Dingin, namun pemikirannya merambah dunia lain yang lebih luas dan dan lebih realistis untuk membangun sebuah fondasi kompleks perdamaian dunia. Keohane memfokuskan karyanya pada issu-issu baru tentang ekonomi politik dunia yang menggeser masalah keamanan internasional, issu tentang aktor-aktor baru dalam hubungan antar bangsa yang tidak lagi 'state centric', tapi berbagai aktor transnasional, issu tentang bentuk-bentuk interaksi internasional baru yang tidak lagi 'interstate relations', melainkan transnasional dan 'transgovernmental relations', issue tentang hasil-hasil baru dari kerjasama internasional yang tidak hanya berbicara tentang konflik antar bangsa, issu tentang struktur institusi internasional baru yang tidak sepenuhnya anarkhis, yang dia hepothesiskan secara provokatif bahwa struktur internasional baru itu akan kokoh setelah menurunnya hegemoni Amerika Serikat (Moravcsik, 2009).

Pemikiran Keohane tersebut merupakan kritikan terhadap pendekatan realisme politik internasional yang sangat dominan pada waktu itu, dimana hubungan internasional digambarkan penuh dengan anarkhisme dan kecenderungan untuk ber-konflik. Keohane menemukan celah untuk membangun fondasi teoritik tentang struktur intitusi dan hubungan internasional yang lebih memberi peluang untuk berkembangnya hubungan damai antar bangsa. 
Dia berkeyakinan bahwa dengan semakinbermunculannya aktor-aktor baru dalam hubungan trasnasional, terutama terkait dengan issuissu ekonomi-politik internasional, hubungan antarbangsa akan lebih cenderung untuk tidak bersifat konfliktual, tetapi hubungan yang saling memberi keuntungan atau positive sum.

"The more fundamental implication of the existance of transnational relations is the following: State preferences about the management of world politics are a potentially positive-sum variable, rather than a zero sum constant, as realists had claimed." (Moravcsik, 2009)

Keohane sangat mengapresiasi konsep tentang managemen konflik internasional yang diungkapkan oleh Thomas Schelling sebagai Strategy of Conflict, di mana cara-cara pemaksimalan potensi kerjasama internasional, secara rasional, akan dapat dicapai oleh para aktor hubungan internasional, dengan mengesampingkan pilihan untuk berkonflik. Keohane berpendapat bahwa regim atau tatanan internasional adalah sangat berharga bagi pemerintahan/negaranegara bukan karena mereka bisa memaksakan ikatan atas negara lainnya, melainkan karena mereka secara sadar melihat kemungkinan bagi pemerintahanya untuk membuat kesepakatan-kesepakatan yang saling menguntungkan satu sama lain. Mereka akan memberdayakan pemerintah mereka daripada membelenggunya.

Kontribusi pemikiran Keohane yang kedua setelah optimisme positive-sum dalam hubungan transnasional ini adalah, bahwa hubungan kekuatan antar negara terbentuk bukan karena kepemilikan sumber-sumber kekuatan yang koersif, tetapi terbentuk dari keadaan yang asimetris terkait isu spesifik dalam hubungan yang saling bergantung antar bangsa. Dalam hubungan saling bergantung yang asimetris, semakin banyak sumber daya dimiliki oleh suatu negara, maka ia akan semakin kuat, namun sebaliknya, makin sedikit yang dimiliki, maka semakin lemahlah negara itu. Bargaining relations mungkin bisa relatif simetris seperti dalam kasus Jerman dan Perancis, dan mungkin juga menjadi asimetris misalnya antara Amerika Serikat dan Guate- mala di masa yang lalu.

Kontribusi pemikiran dari Keohane yang ketiga dalam teori transnasional adalah, mengenai peranan informasi sebagai elemen dasar dalam sistem internasional. Dia berpendapat bahwa, variasi dari sifat dasar dan distribusi informasi adalah suatu variabel sistemik dalam hubungan internasional (world politics) yang membantu menjelaskan kemampuan bangsabangsa dalam mengatasi masalah aksi-aksi bersama. Dengan memahami secara akurat peran yang dimainkan oleh kuantitas, kualitas dan distribusi dari informasi, maka kita dapat memahami dengan baik perilaku negara dalam hubungan internasional, daripada model pemahaman yang hanya mempreferensikan gagasan-gagasan tentang kekuatan (militer) dan strategi (Moravcsik, 2009).

Lebih jauh, Keohane mengidentifikasi ada lima dampak dari terjadinya interaksi transnasional, yakni, pertama, terjadinya attitude change atau perubahan sikap, di mana interaksi antar masyarakat, individu secara langsung antar bangsa akan memberikan alternative sikap dan opini yang berbeda pada setiap orang. Demikian pula dengan jaringan komunikasi transnasional yang ditransmisikan secara elektronik baik dalam bentuk kata-kata, maupun gambar, akan mendorong terjadinya perubahan sikap tersebut. Kedua, terjadinya international pluralism. Yang dimaksud dengan tumbuhnya pluralisme internasional ini adalah semakin eratnya link-link jaringan antar kelompok kepentingan yang berbasis nasional yang mengembangkan jaringan ke tingkat transnasional, dan biasanya dengan melibatkan organisasi transnasional untuk peng-koordinasiannya. Ketiga, terbentuknya dependence and interdependence terutama yang terkait dengan transportasi dan keuangan internasional. Intergrasi sistem keuangan suatu negara ke dalam sistem keuangan global merupakan praktek dependency yang tidak dapat dipungkiri saat ini, sebab keterasingan dalam sistem keuangan ini dapat berakibat sangat serius bagi suatu negara. Sedangkan, kesalingtergantungan dapat dilihat dari kebijakan internasional terkait dengan lingkungan hidup dan global warming. Keempat, peningkatan sikap dari 
beberapa pemerintah dari negara tertentu untuk mempengaruhi negara lainnya. Di sini, interaksi transnasional dimanfaatkan oleh negara-negara tertentu untuk tujuan-tujuan politik, misalnya pariwisata internasional digunakan untuk aktifitas spionase, atau menanamkan rasa simpatik kepada etnis tertentu di negara lain, atau bahkan penumbuhan rasa simpatik terhadap agama tertentu, adalah contoh-contoh bagaimana melakukan penetrasi negara secara informal. Kelima, munculnya aktor-aktor otonom 'non-state' dalam hubungan internasional dengan membawa corak kebijakan luar negeri 'swasta' atau 'private foreign policies' yang kemungkinan akan bertabrakan dengan kepentingan/kebijakan negara atau paling tidak terdapat ketidak sinkronan dengan kebijakan negara. Aktor-aktor ini antara lain kongsi dagang internasional (trade unions), dan MNCs (Keohane dan Nye, 1971).

Sifat hubungan internasional yang bercorak transnasional ini memang menjadi kecenderungan dunia setelah munculnya era globalisasi, maka tidak mengherankan jika pemikir seperti Quincy Wright memaknai hubungan internasional dengan pengertian yang sangat luas dan tidak terkungkung dengan pemikiran yang state-centris. Q. Wright menyatakan bahwa hubungan internasional melibatkan berbagai aktor, antara lain:

“...varied types of groups-nation states, governments, peoples, regions, alliances, confederations, international organizations, even industrial organizations, cultural organizations, religious organization..." (Wright, 1998).

Dengan beragamnya aktor hubungan internasional, baik state actors atau non-state actors, institusi maupun individu, serta kompleksnya interaksi transnasional yang terjadi di dalamnya, maka Keohane selaku peletak dasar-dasar pemikiran teoritis tentang transnasionalisme lebih memilih istilah 'world politics' daripada 'international relations', dengan makna yang lebih dinamis dan luas (Keohane, 2003).

\section{PEMIKIRAN THOMAS C. SCHELLINGS TENTANG THEORY OF INTERDEPENDENT DECISIONS}

Pemikiran Thomas C. Schelling tentang teori keputusan yang saling bergantung atau "The Theory of Interdependent Decisions", yang untuk selanjutnya disingkat TID, secara khusus mendapat apresiasi dari Robert Keohane seperti telah disinggung sebelumnya. Keohane sependapat dengan Schelling bahwa secara rasional dalam interaksi transnasional para aktor akan mengambil tindakan atau aksi yang bersifat positive sum. Teori ini terdapat variasi nama-nama sebutan lain, seperti Schelling's Bargaining Theory, Strategic Theory, dan The Strategy of Conflict. Penulis secara sadar lebih memilih menggunakan sebutan "Theory of Interdependent Decisions" sebab istilah inilah yang diberikan oleh pencetusnya, yaitu Thomas C. Schellings sendiri (Dougherty, 1982).

Sebelum mengkaji teori ini secara lebih jauh, terlebih dahulu akan dedefinisikan apa yang dimaksud dengan 'Interdependent'. Menurut Richard Rosecrance dan Arthur Stein, pengertian istilah ini adalah :

"Interdependence, in the most general sense, as consisting of a relationship of interests such that if one nation's position changes, other states will be affected by that change" (Dougherty, 1982, hal 137).

Adapun yang dimaksud dengan decisions dalam tesis ini adalah kebijakan yang diambil oleh para aktor hubungan internasional baik itu daerah otonom maupun pihak asing (IGO, INGO ataupun aktor-aktor lain). Kebijakan yang dipilih ini merupakan keputusan yang diambil di antara alternatif-alternatif kebijakan lain yang cukup mendapat dukungan dari komunitas yang melingkunginya. Kebijakan ini harus bersifat responsif terhadap perkembangan yang terjadi di lingkungan internasional yang melingkupinya. "Decisions" dalam hal ini disejajarkan dengan pengertian "Out Put" sebagaimana dimaksud oleh David Easton dalam teori sistemnya (Easton dalam Mas'oed, 1991).

Setelah mendefinisikan istilah-istilah pokok di atas, sampailah kini pada pembicaraan mengenai inti dari Teori Keputusan Yang Saling Bergantung ini. Menurut Schellings, "Theory of Interdependent Decisions" (TID) ini mendasarkan diri pada pemikiran bahwa :

"takes conflict for granted, but also assumes common interest between the adversaries; it assumes a 'rational' 
value-maximazing mode of behaviour; and it focuses on the fact that each participant's 'best' choice of action depends on what the expects the other to do, and that 'strategic behaviour' is concerned with influencing another's choice by working on his expectation of how one's own behaviour is related to his" (Dougherty, 1982, hal 527).

Terpapar jelas di sini, bahwa TID dilandaskan pada asumsi bahwa inheren dalam suatu konflik sebagaimna adanya, terdapat pula kepentingan bersama (common interests) di antara pihak-pihak yang terlibat, yang dianggap sebagai suatu bentuk pemaksimalan nilai rasional dari perilaku mereka yang bisa dicapai. Atau dengan kata lain, “common interests' itu merupakan hasil upaya maksimal yang rasional guna mengakomodasikan konflik yang sedang terjadi di antara para aktor hubungan internasional. Pandangan ini berdasar pada kenyataan bahwa pilihan kebijakan terbaik dari setiap perilaku partisipan (aktor-aktor) adalah sangat tergantung dari apa yang mereka harapkan dari pihak lain. Pilihan kebijakan itu dimaksudkan pula untuk mempengaruhi agar perilaku pihak lain sesuai dengan yang diharapkan.

Ada dua pokok pikiran penting dalam teori ini. Pertama, TID memandang konflik bukan semata-mata sebagai saling bersaing atau saling mengancam diantara pihak-pihak yang terlibat saja, tetapi lebih merupakan suatu fenomena yang kompleks, yang di dalamnya antagonisme dan kerjasama sering berinteraksi secara samar dalam hubungan yang berlawanan. Pikiran Schelling ini merefleksikan suatu keyakinan bahwa dalam sebagian besar konflik internasional, misalnya masalah persaingan sumberdaya ekonomi luar negeri, penyelesaian yang bersifat zero sum game adalah tidak relevan.

Pokok pikiran kedua dari TID adalah teori ini memandang bahwa penyelesaian yang bersifat rasional (kalkulatif) merupakan suatu tindakan yang pantas dan harus diupayakan semaksimal mungkin, meskipun, dalam berbagai kasus tidak semua penyelesaian dapat bersifat rasional. Dalam hal ini Schelling mengatakan :

'It is not a universal advantage in situations of conflict to be inalienablyand manifestly rational in decision and motivation...It is not true, as illustrated in the example of extortion, that in the face of threat, it is invariably an advantage to be rational, particularly if the fact of being rational or irrational cannot be concealed' (Dougherty, 1982, hal. 529).

Nyatalah kiranya bahwa rational decision tidak selalu terdapat dalam setiap penyelesaian konflik ataupun pembuatan keputusan ketika menghadapi ancaman. Penyelesaian rasional harus tetap diupayakan terlebih dahulu sebagaimana diyakini sendirti oleh Schelling terutama untuk menyelesaikan masalah-masalah tertentu seperti konflik/masalah ekonomi yang menuntut rasionalitas yang tinggi.

Sumbangan terbesar dari TID dalam menyelesaikan masalah-masalah internasional antara para aktor hubungan antarbangsa adalah perlunya menghindarkan penyelesaian konflik internasional secara extrem atau frontal. Formulasi penyelesaian yang bersifat zero sum game oleh TID diganti menjadi jenis penyelesaian yang bersifat kolaborasi murni (pure collaboration) yang di dalamnya para pihak yang berkonflik berusaha semaksimal mungkin untuk mencari celah kerjasama secara rasional sehingga melahirkan spiral harapanharapan yang saling berbalasan (spiral of reciprocal expectation) guna memformulasikan penyelesaian yang acceptable atas konflik internasional yang terjadi.

Relevansi TID dalam menganalisa penyelesaian masalah antar para aktor hubungan internasional adalah sesuai dengan dua pokok pikiran yang ditawarkan TID di atas, pertama, jenis penyelesaian masalah secara non zero sum game dengan mendorong para aktor untuk melakukan pure collaboration sangat sesuai untuk menganalisa kunci persoalan antar para aktor hubungan internasional yaitu masalah ekonomi atau perebutan sumber-sumber ekonomi luar negeri. Kedua, TID menawarkan bahwa dalam penyelesaian masalah antara para aktor hubungan internasional mendorong upaya pemaksimalan penyelesaian konflik secara rasional, betapun menurut TID ini pula, hal ini tidak dapat berlaku secara mutlak.

Jadi, penggunaan TID dalam menganalisa masalah 
konflik antar para aktor hubungan internasional ini, diharapkan dapat memberikan arah sekaligus sifat penyelesaiannya yaitu pure collaboration dan rational decision. Sebuah optimisme baru di tengah pergaulan dunia yang lebih beradab dan kompleks.

Di samping itu, Keohane juga mengajukan tiga kriteria untuk mengelola resolusi konflik antar negara dan konflik transnasional, yakni 'independence', 'access' dan 'legal embeddedness' di mana lembaga-lembaga internasional memiliki sifat pengambilan keputusan yang mandiri tanpa ada dominasi politik, tekanan luar atau pun ancaman militer dari negara mana pun (individual national governments), serta keterbukaan akses bagi setiap negara untuk menjadi pengambil keputusan, dan adanya keterikatan hukum diantara para aktors transnasional untuk saling mengotrol dan melakukan penegakkan aturan (Keohane, 2000).

\section{PARADIPLOMACY, GELIAT LOKAL DALAM INTERAKSI GLOBAL}

Paradiplomasi secara relatif masih merupakan fenomena baru dalam kajian hubungan internasional. Paradiplomasi mengacu pada perilaku dan kapasitas melakukan hubungan luar negeri dengan pihak asing yang dilakukan oleh entitas sub-state, dalam rangka kepentingan mereka secara spesifik (Wolff, 2009).

Dalam konteks ini, aktor sub-negara diperankan oleh pemerintahan regional atau lokal yang secara tradisional bertindak sebagai aktor dalam negeri. Namun, pada era transnasional, pemerintah regional juga melakukan interaksi yang melintasi batas-batas negara mereka, dan dalam taraf tertentu, mereka juga menyusun kebijakan kerjasama luar negerinya, yang dalam banyak kasus, tidak selalu berkonsultasi secara baik dengan pemerintah pusat. Fenomena pemerintah regional membangun hubungan internasional ini sangat tampak di Negara-negara industri maju di Barat, seperti di Flander-Belgia, Catalonia-Spanyol, the Basque Country, Quebec-Canada (Lecours, 2008).

Terkait bangkitnya geliat partisipasi pemerintah local atau daerah otonom untuk berkiprah secara initernasional ini, Stefan Wolff, lebih lanjut mengatakan;
'The participation of autonomous entities in the international arena indicates that the very notion of sovereignty has fundamentally changed. It can no longer be conceptualised in the exclusive state-only terms of the Westphalian system. For states to enjoy sovereignty to its fullest possible extent and for their populations to benefit from it, states have to share their powers with other players in the international arena. The example of paradiplomacy, however, also clearly indicates that states remain the ultimate bearers of sovereignty: paradiplomacy is, at best, a competence devolved to autonomous entities and hence it is the sovereign state that decides how much of its power it shares' (Wolff, 2009, hal. 13).

Dengan terlibatnya pemerintah lokal dalam melaksanakan hubungan dengan pihak luar negeri, maka itu mengindikasikan bahwa pemikiran paling mendasar tentang kedaulatan Negara telah berubah secara fundamental. Sistem Westphalia yang meletakkan kedaulatan secara penuh pada pemerintah pusat, harus rela shar' dengan pemerintah daerah dalam aktifitas internasionalnya. Seberapa besar share kedaulatan itu, tentu akan berbeda-beda tiap negara.

Studi yang dilakukan oleh David Criekemans menunjukkan bahwa di negara-negara maju, hubungan pusat dan daerah dalam share kedaulatan di bidang hubungan internasional ini ada dua kecenderungan, yakni ada yang bersifat kooperatif dan ada pula yang konfliktual. Paradiplomasi yang dipraktikkan oleh Flanders, Wallonia, dan Bavaria cenderung kooperatif dengan pemerintah pusat, meski masih ada kesan kompetitif, sedangkan interaksi luar negeri yang dilaksanakan oleh Scotland dan Catalonia cenderung konfliktual (Criekemans, 2008).

Dalam konteks Indonesia, paradiplomasi telah diberi ruang yang cukup leluasa oleh pemerintah pusat, terutama setelah adanya era otonomi daerah. Hal ini bisa dibuktikan dengan pernyataan Presiden Susilo Bambang Yudoyono di depan para pengusaha Australia, di Canberra, Australia, 11 Maret 2010, mengatakan bahwa," silakan para pengusaha Australia menghubungi dan menjalin komunikasi dengan pemerintah daerah (kabupaten/kota dan provinsi) di 
Indonesia, terutama para Gubernur untuk mengadakan investasi di Indonesia. Kalau ada kesulitan silakan menghubungi para menteri terkait," (Kompas, 12 Maret 2010). Jalinan kerjasama Pemda dengan pihak asing ini ditegaskan oleh Presiden SBY karena disadari sepenuhnya bahwa tanpa kerjasama dengan investor asing atau pihak asing lainnya seperti pemerintah asing dan organisasi/foundation asing, pertumbuhan ekonomi daerah akan sulit didorong untuk berkembang lebih cepat.

Pernyataan Presiden tersebut memang dilandasi oleh undang-undang yang memberikan peluang bagi daerah untuk melakukan kerjasama dengan pihak asing. Dalam UU Nomor 32 Tahun 2004, kewenangan daerah otonom untuk melakukan kerjasama luar negeri ini terdapat dalam pasal 42 ayat (1), bahwa DPRD mempunyai tugas dan wewenang untuk memberikan persetujuan terhadap rencana kerjasama internasional yang dilakukan oleh pemerintah daerah. Ditegaskan pula dalam penjelasan pasalnya bahwa selain sister city/province, Pemda juga dapat membuat perjanjian kerjasama teknik termasuk bantuan kemanusiaan, kerjasama penerusan pinjaman/ hibah, kerjasama penyertaan modal dan kerjasama lainnya sesuai dengan peraturan perundang-undangan.

Kerjasama luar negeri oleh daerah otonom jika dilihat dari sudut pandang studi hubungan internasional, secara teoritis, merupakan hubungan yang tidak lagi bersifat state-centris di mana aktor-aktor non-pemerintah dapat secara leluasa mem-by pass hubungan dengan tanpa melibatkan pemerintah pusat. Hal ini disebabkan adanya perbedaan sistem hukum yang berlaku di NKRI dengan hukum yang berlaku di negara asing yang akan bekerjasama, dimana beberapa gubernur/walikota dari negara asing dapat langsung membuat/menandatangani kerjasama internasional tanpa 'full power' dari pemerintah pusatnya (contoh Propinsi Geongsangbuk-Do dan Chungnam-Do di Korea Selatan, Provinsi/Kota-kota di Cekoslovakia, serta Negara Bagian California, USA). Dalam hubungan yang 'non-state centris' ini, aktor-aktor dapat berwujud INGO, foundation, kelompok kepentingan ekonomi, perusahaan multinasional dan bahkan bagian-bagian dari birokrasi pemerintah suatu negara (pemda).

Dalam pelaksanaan kerjasama luar negeri oleh daerah otonom atau paradiplomasi di Indonesia terdapat beberapa masalah utama, antara lain; pertama, terdapat kerancuan hukum nasional yang mengatur kewenangan ini terutama terkait dengan kewenangan interdepartemental yang harus menangani, yakni overlap antara kewenangan Kementerian Luar Negeri dengan Kementerian Dalam Negeri. Masingmasing memproduk aturan hukum yang berbeda untuk pemerintah daerah sehingga mempersulit koordinasi vertikal. Kedua, terdapat desentralisasi asimetris di Indonesia, yakni perbedaan antara Provinsi Aceh dan Papua yang perlakuan prossedurnya tidak sama dengan pemerintah daerah/provinsi lainnya. Ketiga, kesiapan daerah yang belum prima, terutama terkait dengan sumberdaya insani birokrasi dan pembeayaan aktifitas kerjasama luar negeri yang relatif besar.

\section{KESIMPULAN}

Hubungan transnasional yang mewarnai sistem interaksi masyarakat dunia pasca regim Westphalia memiliki karakter yang lebih partisipatif bagi semua aktor internasional, baik pada tingkat negara, maupun lokal, institusional atau pun individual. Spirit positive sum dan pure colaboration, yang diajukan sebagai transnational values, akan lebih memberikan pengharapan bagi terciptanya dunia yang lebih beradab.

Interaksi transnasional yang memunculkan aktoraktor sub state dalam menjalin aktifitas paradiplomasi, tidak serta merta menghapuskan sendi utama kedaulatan negara, namun melahirkan sebuah tuntutan untuk pengaturan lebih lanjut tentang komitmen negara untuk melakukan share kedaulatan dalam batas-batas konstitusinya. Di sinilah, pada praktik paradiplomasi di negara-negara maju, fakta tentang tarik ulur pembagian kedaulatan itu terjadi.

Dalam konteks Indonesia, paradiplomasi masih merupakan praktek berpemerintahan yang baru sehingga memerlukan perangkat yuridis yang jelas di 
tengah pelaksanaan desentralisasi atau otonomi daerah saat ini.

\section{REFERENSI}

Criekemans, David, 'Are The Boundaries between Paradiplomacy and Diplomacy Watering Down?', hal. 12-13, University of Anwerp and Flemish Centre for International Policy, Belgium, July 2008

Dougherty, James E. dan Pfaltzgraff, Robert L., Jr., 'Contending Theories of International Relations', , hal. 527, Harper and Row, Publishers, New York, 1982

Easton, David, 'An Approach to the Analysis of Political System', dalam Mohtar Mas'oed, Perbandingan Sistem Politik, Gadjah Mada Univ. Press, YK, Tahun 1991, hal. 5

Inanc, Hüsamettin dan Ozler, Hayrettin, dalam, 'Democratic Deficit in EU: Is there an institutional solution to over-institutionalization?' Alternatives: Turkish Journal of International Relations, Vol. 6, No.1\&2, hal. 127, Turkey, Spring \& Summer 2007

Jackson Robert, dan Sorenson, Georg dalam, 'Introduction to International Relations', Oxford University Press Inc., New York, 1999. Dalam edisi Bahasa Indonesia diterjemahkan oleh Dadan Suryadipura, Pustaka Pelajar Offset, Yogyakarta, 2009

Keohane, Robert, 'Power and Governance in a Partially Globalized World', hal 2-40, Rouledge, London, 2002

Keohane, Robert, and Nye, Joseph S. Jr., 'Transnational Relations and World Politics', hal. 337-341, Summer 1971. Published by International Organization Vol. 3, No. 3, JSTOR, USA, 2003

Keohane, Robert, 'Theory of World Politics: Structural Realism and Beyond', hal. 165, dan hal. 195-196, International Organization, JSTOR, 2003

Keohane, Robert, Anne-Marie Slaughter, 'Legalized Dispute Resolution: Interstate and Transnational', International Organization 54, 3, hal. 457-460, The IO Foundation and Massachusetts Institute of Technology, USA, Summers 2000

Lecours, André, 'Political Issues of Paradiplomacy: Lessons from the Developed World',

Hal. 1, Netherlands Institute of International Relations 'Clingendael', December 2008,

Moravcsik, Robert, 'Robert Keohane: Political Theorist', dalam 'Power, Interdependence, and Nonstate Actors in World Politics', Helen V. Milner dan Andrew Moravcsik (Editor), Chapter 3, hal 244, Princeton University Press, Princeton and Oxford, 2009

Osiander, Andreas, 'Sovereignty, International Relations and Westphalian Myth', International Organization 55, hal. 251, The IO Foundation and Massachusetts Institute of Technology, USA, Spring 2001

Stefan Wolff, 'Paradiplomacy: Scope, Opportunities and Challenges', hal. 1-2, dan 13, University of Nottingham, 2009

Wright, Quincy, The Study of International relations, seperti dikutip dalam bukunya Suwardi Wiriaatmaja, Pengantar Ilmu Hubungan Internasional, Penerbit Pustaka Tinta Mas, Bandung, 1988

Kompas, 12 Maret 2010

Undang-Undang No. 32 Tahun 2004 tentang Pemerintahan Daerah, SETNEG, Tahun 2004

http://www.nato.int/docu/speech/1998/s981112a.htm

http://www.theory-talks.org/2008/05/theory-talk-7.html. Theory Talks is an initiative by Peer Schouten and is registered as ISSN 2001-4732 | 2008-2012. Beberapa wawancara Theory Talks telah diterbitkan dalam Bahasa Indonesia dengan judul "Theory Talks, Perbincangan Pakar Sedunia Tentang Teori Hubungan Internasional Abad Ke-21", Editor: Bambang Wahyu Nugroho dan Hanafi Rais, PPSK dan LP3M UMY, Yogyakarta, 2012 